\title{
Influence of Sahelian and Sudanian provenances on the physical and mechanical properties of Faidherbia albida wood from Chad
}

Dao Dougabka, Jean Gerard, Tikri Bianzeube, Remy Marchal, Daniel Guibal \& Alban Guyot

To cite this article: Dao Dougabka, Jean Gerard, Tikri Bianzeube, Remy Marchal, Daniel Guibal \& Alban Guyot (2021): Influence of Sahelian and Sudanian provenances on the physical and mechanical properties of Faidherbia albida wood from Chad, Wood Material Science \& Engineering, DOI: 10.1080/17480272.2021.1929467

To link to this article: https://doi.org/10.1080/17480272.2021.1929467

\section{曲 Published online: 18 May 2021.}

Submit your article to this journal $\widetilde{ }$

View related articles

View Crossmark data $\rtimes$ 


\title{
Influence of Sahelian and Sudanian provenances on the physical and mechanical properties of Faidherbia albida wood from Chad
}

\author{
Dao Dougabka $^{a, b, c}$, Jean Gerard ${ }^{a, b}$, Tikri Bianzeube ${ }^{c}$, Remy Marchal ${ }^{d}$, Daniel Guibal ${ }^{a, b}$ and Alban Guyot ${ }^{a, b}$ \\ a UPR BioWooEB, CIRAD, Montpellier, France; ${ }^{b}$ BioWooEB, Univ Montpellier, CIRAD, Montpellier, France; 'Université Polytechnique de Mongo, \\ N'Djamena, Tchad; ${ }^{d}$ Arts et Metiers Institute of Technology, LABOMAP, HESAM Université, Cluny, France
}

\section{ABSTRACT}

Faidherbia albida is a typical emblematic species of African dryland areas. In Chad, it is used for many purposes, but very little is known about the technological properties of its wood, which sometimes leads to inappropriate uses. This work consisted to study the physical and mechanical properties of this wood, collected in the Sahelian and Sudanian chadian zone. As well as the impact study of the sampling areas of these properties. The result obtained shows that, the density, infradensity; modulus of elasticity, compression strength were significantly higher in the Sahelian zone than in the Sudanian zone, i.e. 508 and $409 \mathrm{~kg} \cdot \mathrm{m}^{-3} ; 5555$ and $23.7 \mathrm{MPa}$, compared to 444 and $359 \mathrm{~kg} \cdot \mathrm{m}^{-3} ; 4150$ and 19.6 MPa. The total tangential shrinkage, total volumetric shrinkage, fibre saturation point; static bending strength were significantly lower in wood from the Sahelian zone compared to the Sudanian zone, i.e. $4.6 \%$, $7.7 \%, 23.7 \% ; 42.5 \mathrm{MPa}$, compared to $6.6 \%, 9.5 \%, 28.9 \%$; $52.6 \mathrm{MPa}$. The total radial shrinkage values obtained were not significantly different between the two provenances (mean: $3.1 \%$ ).
ARTICLE HISTORY

Received 26 March 2021

Revised 3 May 2021

Accepted 5 May 2021

KEYWORDS

Faidherbia albida; wood; physical properties; mechanical properties; Chad

\section{Introduction}

Faidherbia albida (Delile) A. Chev. belongs to the Fabaceae family (Mimosaceae subfamily). This species is found throughout dryland areas of Africa and the Middle East, as well as in Asia where it has been introduced (Wood 1989).

It is an emblematic species in the Sahelian region, where it is used for many purposes. F. albida trees can grow to $15-20 \mathrm{~m}$ in height with a trunk diameter of about $1 \mathrm{~m}$. The leaves and fruit are used as livestock feed (Kini 2018). Moreover, its soft, light yellow wood is used for making art objects (sculpture), kitchen utensils (pestles, mortars, gourds, etc.), building huts and granaries, and as fuelwood. Its bark and roots are used in traditional medicine. This species has a particularly remarkable ability to improve the soil quality, while also being unique for its reverse phenology feature. Studies of, Sileshi (2016) and Dilla et al. (2019) have shown that F. albida improves soil quality by fixing nitrogen from the air, as do many Fabaceae species, but also by bringing mineral elements from the deep soil horizons and to the surface. These trees bear leaves, flowers, and fruit in the dry season and then lose them completely in the rainy season, thereby facilitating intercropping, so it is an ideal agroforestry tree (Depommier 1998).

Moreover, the studies of Mignon and Do (1999) and Roupsard et al. (1999) showed that $F$. albida is a phreatophyte species, i.e. it absorbs water from the water table to meet its metabolic needs. This characteristic was highlighted in a study of its root system and drought tolerance. Wood (1989) showed that tap roots of $F$. albida trees growing on sand dunes can reach a depth of over $5 \mathrm{~m}$ within 1 year these roots stop growing when they have reached a sufficient depth to fulfil the tree's water needs.
In Chad, the vegetation consists mainly of small and thorny trees. Some species such as F. albida are used specially to meet wood needs in rural areas. These species are not marketed and their wood quality has only been studied in a piecemeal manner. However, it is essential to gain insight into their technological characteristics and their variations in order to better understand their technological behaviour and enhance their use.

In local markets, end users show a preference for products and objects made from wood from the Sahelian zone where growing conditions are unfavourable compared to the more favourable conditions in the Sudanian zone (rainfall, temperature). Items made with wood from the Sudanian zone are generally less resistant with a greater tendency to split and deform than wooden items from the Sahelian zone.

In their study of F. albida from eastern and southern Africa (Taveta in Kenya, Lupaso and Wangingombe in Tanzania, Kuiseb in Namibia, Manapools in Zimbabwe), Koech et al. (2016) showed that provenances from the driest areas with the least rainfall had better growth than those located in areas under high rainfall conditions.

One of the aims of this study was to highlight differences in wood quality when comparing the reference technological properties of the two studied provenances. By gaining greater insight into the properties of $F$. albida wood, farmers would be able to better tailor its uses, in turn generating additional income, while encouraging them to plant this species in agroforestry systems.

The results obtained will also enable us to assess the impact of the species' phreatophyte feature on these properties. 


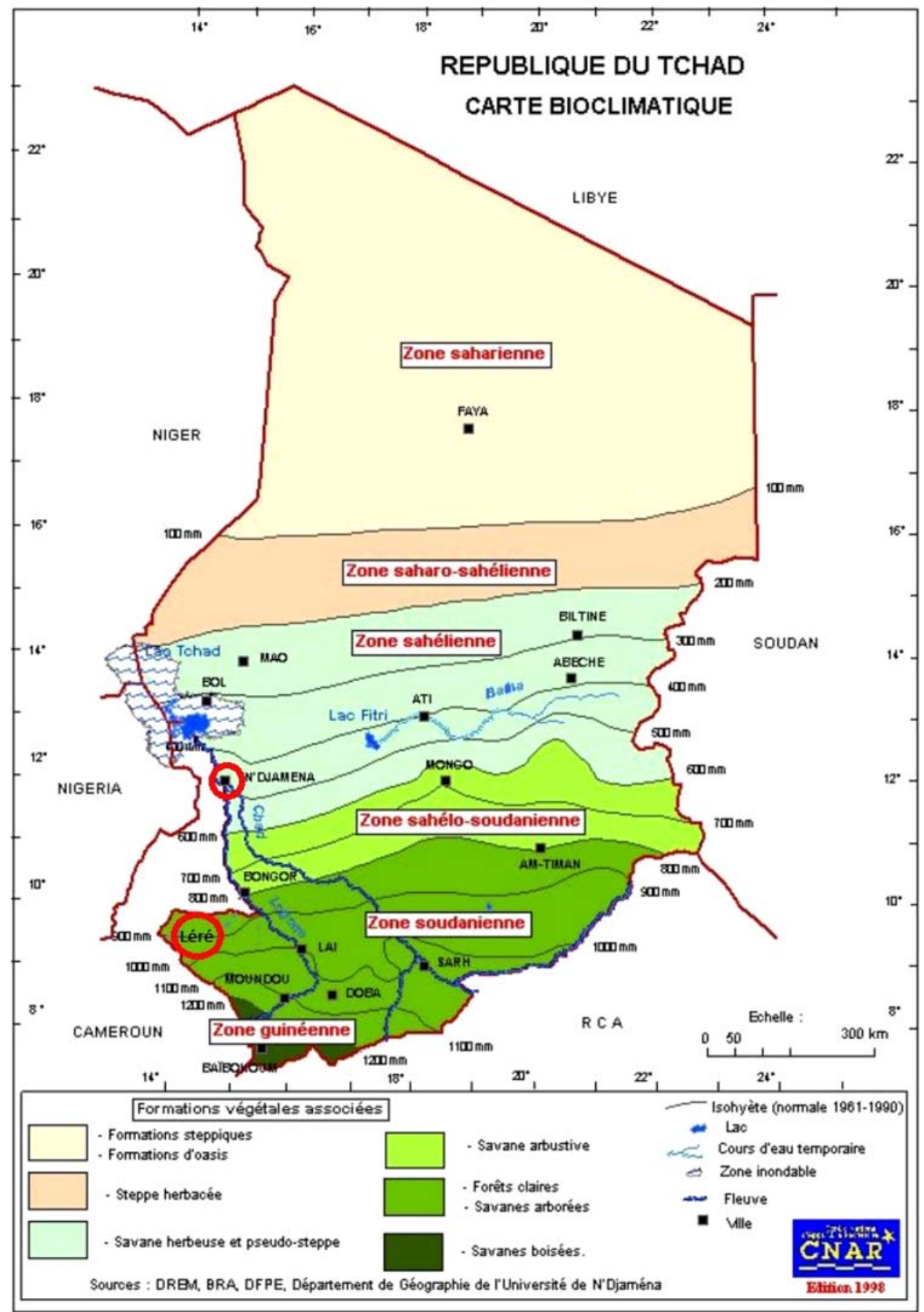

Figure 1. Bioclimatic map of Chad.

The following properties were selected for this study:

(1) Indicators of the physical stability of $F$. albida wood: density, infradensity, total radial drying shrinkage, total tangential drying shrinkage, total drying shrinkage and fibre saturation point. These characteristics are major indicators of the wood quality and its stability after usage (Mazet and Nepveu 1991, Kržišnik et al. 2019), while being closely related to its structure and providing information on its technological behaviour in relation to the growth conditions.
(2) Indicators of mechanical behaviour: longitudinal modulus of elasticity, static bending strength and longitudinal compression strength.

\section{Materials and method}

\subsection{Study areas, sampling method and test specimen processing technique}

The woods studied were sampled in N'Djamena and Léré regions in Chad, located in two different climatic zones (Figure 1): 
Table 1. GPS coordinates and dendrometric data.

\begin{tabular}{lccccc}
\hline Provenance & $\begin{array}{c}\text { Tree } \\
\text { number }\end{array}$ & $\begin{array}{c}\text { Longitude } \\
\text { (decimal } \\
\text { degrees) }\end{array}$ & $\begin{array}{c}\text { Latitude } \\
\text { (decimal } \\
\text { degrees) }\end{array}$ & $\begin{array}{c}\text { Trunk } \\
\text { height } \\
(\mathrm{m})\end{array}$ & $\begin{array}{c}\text { Diameter } \\
(\mathrm{cm})\end{array}$ \\
\hline Sahelian & 1 & 15.10173 & 12.05051 & 3.62 & 27.98 \\
zone & 2 & 15.10222 & 12.05081 & 2.87 & 29.37 \\
& 3 & 15.10227 & 12.05078 & 2.96 & 28.08 \\
& 4 & 12.05056 & 15.10223 & 3.10 & 29.96 \\
Sudanian & 1 & 14.08860 & 9.64318 & 3.46 & 27.6 \\
zone & 2 & 14.08470 & 9.64110 & 3.38 & 29.10 \\
& 3 & 14.08915 & 9.64488 & 2.78 & 28.55 \\
\hline
\end{tabular}

- The Sahelian zone (N'Djamena) characterised by $556 \pm$ $121 \mathrm{~mm}$ average annual rainfall with a $15-44^{\circ} \mathrm{C}$ temperature range (1984-2018).

- The Sudanian zone (Léré) with $860 \pm 114 \mathrm{~mm}$ average annual rainfall and a $25-35^{\circ} \mathrm{C}$ temperature range (19802015) (Climate data source: Agence National de la Météorologie (ANAM-Chad)).

The plant material was in located reforestation sites and was sampled despite the prevailing administrative and logistical stress and constraints. This involved seven trees with a trunk diameter of $27-30 \mathrm{~cm}$ (Table 1). Four were sampled in the Sahelian zone and three in the Sudanian zone. The average tree age was estimated at between 20 and 25 years.

Trees selected was based on their diameter, growth habit and health status, i.e. conventional selection criteria for timber applications (Charron et al. 2003).

The test specimens were obtained using the following process:

- Each tree was felled $50 \mathrm{~cm}$ above the ground. This felling height was set to technically facilitate the operation (manual felling).

- A first log of about $1 \mathrm{~m}$ long above the cut was selected from each trunk.

- A diametric $60 \mathrm{~cm}$ long $\times 6 \mathrm{~cm}$ thick block was cut from each log.

- The seven sampled blocks were initially dried for three months under cover in natural ambient conditions at the felling site in Chad, and then they were stabilised at CIRAD-Montpellier (France) in a climatic chamber at $20^{\circ} \mathrm{C}$ and $65 \%$ relative humidity (climatic conditions allowing the wood to be stabilised at a theoretical $12 \%$ moisture content).

- After three weeks of stabilisation, positions where the test specimens were to be sampled were marked on the block cross-sections. These positions were determined to ensure that the specimen sections would be properly radially and tangentially oriented.

- The specimens (nominal cross-section plus an extra dimension) were cut from the blocks and then further stabilised under a controlled atmosphere at $20^{\circ} \mathrm{C}$ and $65 \%$ relative humidity to a constant weight.

- After a final stabilisation step, these specimens were machined into $20 \times 20 \mathrm{~mm}^{2}$ (radial $\times$ tangential dimension) bars with a length equalling that of the initial block. Three groups of $20 \times 20 \mathrm{~mm}^{2}$ specimens, but of different lengths $(L)$, were cut from these bars, depending on the type of test to be carried out:

$L=360 \mathrm{~mm}$ for bending tests;

$L=60 \mathrm{~mm}$ for compression tests;

$L=10 \mathrm{~mm}$ for assessment of physical properties.

In each of the 7 blocks corresponding to the 7 sampled trees, 6-12 bars were machined, i.e. 29 bars for the Sahelian zone and 27 bars for the Sudanian zone. The number of bars machined in each block depends on the trees diameter. In each bar, 3 specimens were cut, i.e. 87 specimen for the Sahelian zone and 81 specimens for the Sudanian zone as mentioned in Table 2.

All the tests were carried out at CIRAD-Montpellier.

\subsection{Test methods}

\subsubsection{Physical properties}

The reference physical properties studied were 12\% MC density, infradensity, total radial drying shrinkage, total tangential drying shrinkage, total volume shrinkage and fibre saturation point.

Two other properties were also assessed: total volume shrinkage coefficient and shrinkage anisotropy.

The $12 \%$ density was determined simultaneously with the longitudinal modulus of elasticity. The corresponding measuring method is described in section Mechanical properties.

The other five physical properties were determined in a single procedure on the same specimens.

These specimens were first soaked to saturation in distilled water for three days and then they underwent three vacuumpressure cycles in an autoclave to expel any air pockets trapped in the wood.

After saturation, the specimens were weighed and their radial and tangential dimensions measured.

Their saturated volume was determined by the double weighing method according to the Archimedes' thrust

Table 2. Physical and mechanical properties of $F$. albida from chadian Sahelian and Sudanian zones.

\begin{tabular}{|c|c|c|c|c|c|c|c|c|c|c|c|}
\hline Provenances [number of specimens] & Statistic & $\operatorname{Rr}(\%)$ & Rt (\%) & $\operatorname{Rv}(\%)$ & Anis & PSF (\%) & Id $\left(\mathrm{kg} / \mathrm{m}^{3}\right)$ & $\operatorname{Mv}\left(\mathrm{kg} / \mathrm{m}^{3}\right)$ & $\mathrm{C}_{12}(\mathrm{MPa})$ & $\mathrm{F}_{12}(\mathrm{MPa})$ & $\mathrm{E}_{12}(\mathrm{MPa})$ \\
\hline \multirow[t]{3}{*}{ Sudanian zone [87] } & Average & 3.1 & 6.6 & 9.5 & 2.2 & 28.9 & 359 & 444 & 19.6 & 52.6 & 4150 \\
\hline & $S d$ & 0.63 & 0.91 & 1.43 & 0.34 & 2.7 & 46.5 & 42.6 & 3.3 & 11 & 884 \\
\hline & $\mathrm{CV}$ & 20.6 & 13.8 & 15 & 15.4 & 9.5 & 12.9 & 9.6 & 16.7 & 21 & 21.3 \\
\hline \multirow[t]{3}{*}{ Sahelian zone [81] } & Average & 3.1 & 4.6 & 7.7 & 1.5 & 23.7 & 409 & 508 & 23.7 & 42.5 & 5555 \\
\hline & $S d$ & 0.44 & 0.62 & 1.16 & 0.19 & 1.3 & 37.2 & 38 & 3.1 & 11 & 1449 \\
\hline & $\mathrm{CV}$ & 14.4 & 13.5 & 15 & 12.2 & 5.4 & 9.1 & 7.5 & 13.2 & 26 & 13.2 \\
\hline
\end{tabular}

Note: Rr: total radial shrinkage; Rt: total tangential shrinkage; Rv: total volumetric shrinkage; Anis: shrinkage anisotropy; PSF: fibre saturation point; Id: infradensity; Mv: $12 \%$ density; $C_{12}$ : longitudinal compression strength; $F_{12}$ : static bending strength; $E_{12}$ : longitudinal modulus of elasticity; $C V$ : coefficient of variation; Sd: Standard deviation. 
principle: this volume was determined by the weight of the volume of water displaced when a test tube was immersed in a beaker filled with water weighed before and after immersion.

After this first stage of measurements in the saturated state, and in order to determine the fibre saturation point (FSP), the specimens were stabilised in a climatic chamber successively at $85 \%$ ambient relative humidity and $30^{\circ} \mathrm{C}$ (equilibrium moisture content [EMC] of the wood close to $18 \%$ ), $65 \%$ ambient relative humidity and $20^{\circ} \mathrm{C}$ (EMC close to $12 \%$ ), and then $30 \%$ ambient relative humidity and $20^{\circ} \mathrm{C}$ (EMC close to 6\%).

They were finally oven dried to an anhydrous state at $103^{\circ}$ C. According to the French NF EN 13183-1 standard of June 2002, a wood sample is considered anhydrous when the variation in its mass between two successive weighings within a $2 \mathrm{~h}$ interval does not exceed $0.1 \%$.

The specimen densities and radial and tangential dimensions were measured in each stabilised state.

2.2.1.1. Infradensity. The infradensity of a sample is the ratio between its anhydrous mass $\left(M_{\mathrm{a}}\right)$ and its saturated volume $\left(V_{s}\right)$, expressed in $\mathrm{kg} / \mathrm{m}^{3}$. This reference characteristic has the advantage of being easy to determine when a climatic room is not available to stabilise samples at controlled temperature and humidity conditions.

$$
d=\frac{M_{\mathrm{a}}}{V_{\mathrm{s}}}
$$

2.2.1.2. Total linear cross-sectional shrinkage. Linear crosssectional drying shrinkage is an indicator of dimensional variations in wood when its moisture content falls below the fibre saturation point. This dimensional variation is different in the tangential and radial directions of the wood. It is expressed as a percentage and is calculated according to the following formula (NF B 51-006 standard, September 1985):

$$
R_{\mathrm{T}, \mathrm{R}}=\frac{e_{\mathrm{S}}-e_{0}}{e_{\mathrm{S}}}
$$

where $e_{\mathrm{s}}$ and $e_{\mathrm{o}}$ are respectively the dimensions of the samples in the saturated and anhydrous state according to the direction considered.

$R_{\mathrm{T}}>R_{\mathrm{R}}$ always applies regardless of the type of wood considered.

2.2.1.3. Shrinkage anisotropy. The wood shrinkage anisotropy is determined by the tangential to radial shrinkage ratio.

This parameter is a good indicator of the extent of deformation of a piece of wood subjected to humidity variations, and of the stability of wood during its drying and usage (Gérard et al. 2016).

When the $R_{\mathrm{T}} / R_{\mathrm{R}}$ ratio is greater than 2 , it is considered that the studied wood is likely unstable and prone to splitting and deformation.

2.2.1.4. Total volumetric shrinkage. The total drying volumetric shrinkage $\left(R_{\mathrm{B}}\right)$ corresponds to the volume variation of a wood specimen between the saturated and anhydrous state.
Since the longitudinal shrinkage is usually very small compared to transverse linear shrinkage, the sum of the radial and tangential shrinkage $\left(R_{\mathrm{R}}+R_{\mathrm{T}}\right)$ provides a good approximation of the volume shrinkage.

$$
R_{\mathrm{B}}=\frac{V_{\mathrm{s}}-V_{\mathrm{a}}}{V_{\mathrm{s}}} \cong R_{\mathrm{R}}+R_{\mathrm{T}}
$$

where $V_{s}$ is the saturated volume and $V_{a}$ is the anhydrous volume.

2.2.1.5. Fibre saturation point. The fibre saturation point (FSP) is the moisture content of wood saturated with bound water, below which the wood dimensions vary according to the ambient humidity.

It usually ranges from $20 \%$ to $40 \%$ depending on the species, but is generally around $30 \%$ (Gérard et al. 2016).

The FSP is obtained by stabilising the wood samples at different moisture contents between the saturated and anhydrous state, at ambient temperature and relative humidity conditions corresponding to theoretical wood moisture contents of successively around $18 \%, 12 \%$ and $6 \%$. The specimen weights and dimensions are measured at each stage. The exact moisture content of the specimens is determined at the end of the experiment after they have been weighed in the anhydrous state.

The fibre saturation point (FSP) is determined from the intercept of the regression lines between the cross-sectional area variations of the specimens and their moisture content (Figure 2): [Moisture content] $=f$ [Area variations]. It corresponds to the moisture content above which the dimensional variations are zero (Kokutse et al. 2010).

The wood FSP values below $25 \%$ are considered low, medium for values between $25 \%$ and $35 \%$, and high for values above 35\% (Gérard et al. 2016).

\subsubsection{Mechanical properties}

The reference mechanical properties studied were the longitudinal modulus of elasticity, static bending tensile strength and longitudinal compressive strength.

\subsubsection{Measurement of the longitudinal modulus of elas-} ticity and density by the vibration method. A BING@ (Beam Identification by Non-destructive Grading) device was used for this measurement method. This non-destructive method

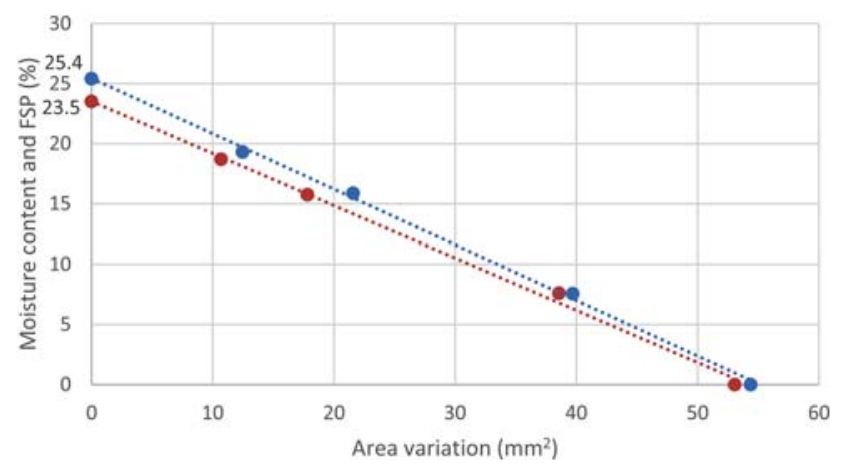

Figure 2. Example FSP determination of two $F$. albida specimens. 
was developed at CIRAD. It is based on the study of vibrations of a wood specimen or any other material. The device may be used to determine the elastic characteristics (longitudinal modulus of elasticity, transverse shear modulus) of any rigid material. A thin specimen with regular geometrical features must be used for the measurement operation, while controlling the support conditions. The specimen is subjected to longitudinal or transverse vibrations and the studied characteristics determination is based on the recording and its analysis.

The measurement principle consists of analysing the resonance Eigen frequencies obtained after an impulse excitation on one of the ends of a specimen resting on two elastic support holders of low rigidity.

The measurements were carried out on $360 \times 20 \times 20 \mathrm{~mm}^{3}$ specimens stabilised at $12 \%$ moisture content.

2.2.2.2. Longitudinal compression strength. The longitudinal compression strength was determined according to the measurement method defined by the NF ISO 13061-17 (June 2018) standard. Measurements were obtained on standardised longitudinally oriented specimens $(60 \times 20 \times 20$ $\mathrm{mm}^{3}$ ), and stabilised in climate-controlled chamber at $12 \%$ humidity. The tests were carried out on an ADAMEL universal testing machine equipped with a $100 \mathrm{KN}$ maximum load cell. This machine consists of a fixed swivel plate upon which the sample is placed and a load cell to apply compression force to the sample. The test speed is $0.01 \mathrm{~mm} / \mathrm{s}$. A computer is used for data acquisition (load, displacement).

2.2.2.3. Static bending strength. The static bending strength was determined according to the French standard NFB51-008 (26 July 2017). The test was carried out on $360 \times 20 \times 20 \mathrm{~mm}$ specimens that had previously been used for the longitudinal modulus of elasticity tests. The machine used was the same as that used for the compression tests after adapting the frame. The testing time was $1.5 \pm 0.5 \mathrm{~min}$.

The maximum stress was determined according to the following equation:

$$
\sigma=\frac{3 P(I-a)}{2 b h^{2}}
$$

where $\sigma$ is the bending tensile strength (MPa); $P$ is the total tensile strength $(\mathrm{N}) ; \boldsymbol{l}$ is the distance between frame rollers $(320 \mathrm{~mm}) ; a$ is the distance between upper rollers $(160 \mathrm{~mm}) ; b$ is the specimen width $(\mathrm{mm}) ; h$ is the specimen height $(\mathrm{mm})$

At the end of the test, the specimen moisture contents were determined according to the procedure defined in the NF EN 13183-1 standard (June 2002).

\section{Results and discussion}

\subsection{Descriptive statistics of the measured properties}

The data processing and analyses were performed using the XLSTAT-Student 2019.4.1 software package.
Table 2 presents the descriptive statistics regarding the F. albida physical and mechanical properties obtained for the two Chadian climatic zones.

\subsection{Observed trends and comments on the measured wood properties}

\subsubsection{Physical properties}

F. albida woods from the Sudanian and Sahelian zones had the same mean radial shrinkage value (3.1\%), but the first zone results showed greater dispersion than those of the second (coefficient of variation of $20.6 \%$ and $14.4 \%$, respectively). Yet the radial shrinkage coefficient was higher for the Sahelian zone compared to the Sudanian zone, i.e. 0.13\%/\% vs. $0.11 \% / \%$, respectively.

The mean tangential shrinkage was $6.6 \%$ in wood from the Sudanian zone vs. $4.6 \%$ for the Sahelian zone, but there was relatively little dispersion in the results (coefficient of variation of $13.8 \%$ and $13.5 \%$, respectively).

The volumetric shrinkage values were higher for the Sudanian zone than for the Sahelian zone, i.e. $9.5 \% \pm 1.43$ vs. $7.7 \%$ \pm 1.16 , respectively.

The shrinkage anisotropy value was higher in wood from the Sudanian zone compared to the Sahelian zone, i.e. 2.2 vs. 1.5 , respectively, due to the higher tangential shrinkage in wood from the second zone, while there was little dispersion in the results for the two zones (coefficient of variation of $15.4 \%$ and $12.2 \%$, respectively).

The fibre saturation point was higher in specimens from the Sudanian zone than in those from the Sahelian zone, i.e. $28.9 \%$ vs. $23.7 \%$, respectively, with a higher dispersion in the results for the first zone (9.5\% vs. 5.4\%).

Infradensity and density at $12 \%$ were lower in wood from the Sudanian zone than in specimens from the Sahelian zone (359 and $444 \mathrm{~kg} \cdot \mathrm{m}^{-3}$ vs. 409 and $508 \mathrm{~kg} \cdot \mathrm{m}^{-3}$, respectively), but with higher dispersion of the results for the first zone (12.9\% and $9.6 \%$ vs. $9.1 \%$ and $7.5 \%)$.

\subsubsection{Mechanical properties}

The longitudinal modulus of elasticity and the compression strength were lower in specimens from the Sudanian zone compared to the Sahelian zone, i.e. $4150 \pm 884$ and $19.6 \pm$ 3.3 MPa vs. $5555 \pm 1449$ and $23.7 \pm 3.1 \mathrm{MPa}$, respectively.

On the other hand, the bending tensile strength was higher for the Sudanian zone than for the Sahelian zone, i.e. 52.6 vs. $42.5 \mathrm{MPa}$, respectively, with high dispersion in the results (coefficient of variation of $21 \%$ and $26 \%$, respectively).

For the two provenances, the values of longitudinal modulus of elasticity are low in regard to density. Explanation could be given through further anatomical investigation of wood.

\subsection{Influence of provenances on the wood properties}

In order to validate the actual impacts of provenances on the studied properties, a graphical statistical analysis was conducted that involved comparing the data distributions presented in the form of notched boxplots (Figure 3), graphical representations generated from Mood's tests (non- 

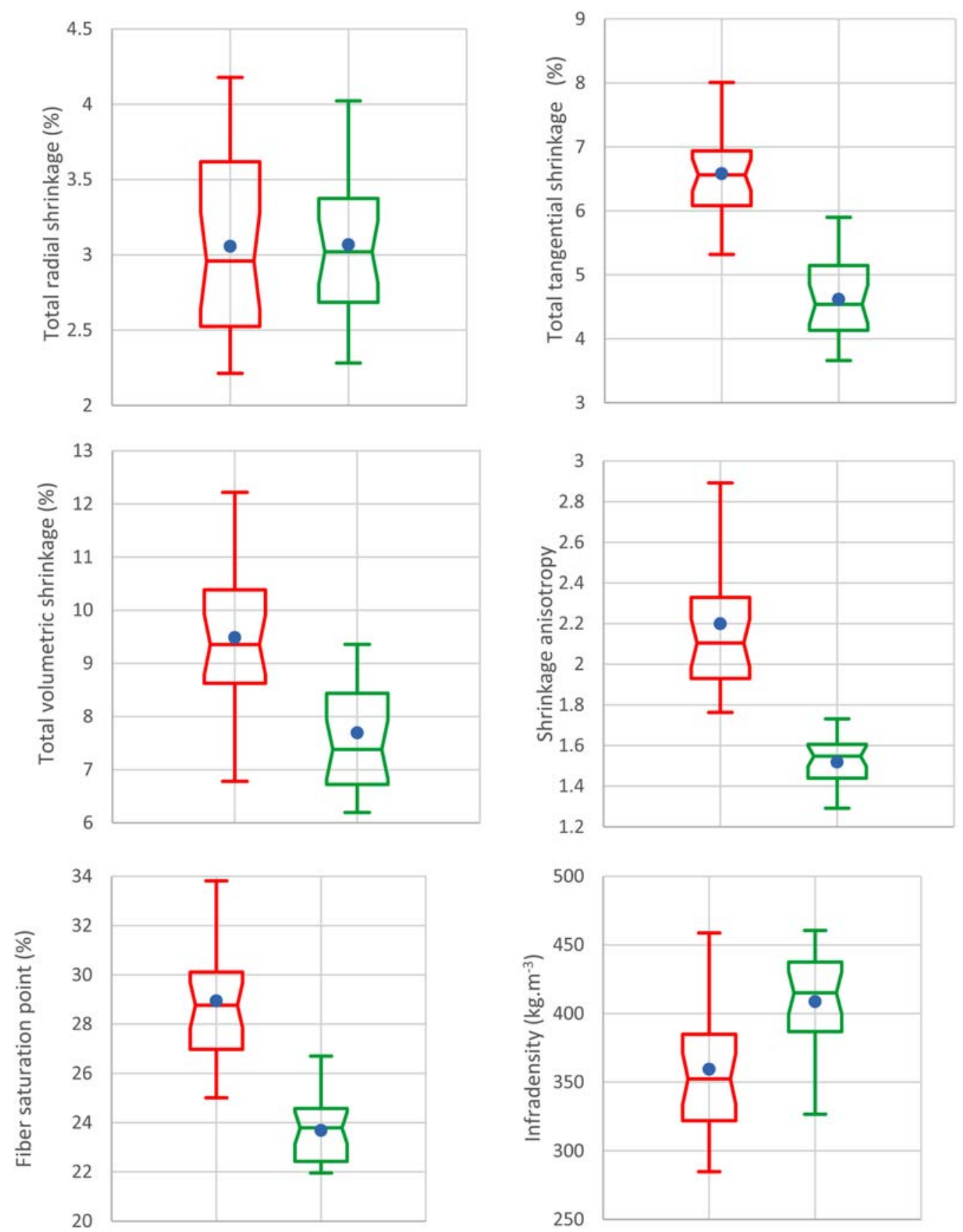

Figure 3. Distribution of $F$. albida wood properties according to provenance.

parametric tests tailored for small datasets). These representations helped highlight differences or the absence of significant differences between the two provenances for each of the properties studied.

The interpretation principle for these graphs was based on a comparison of medians, as represented by central horizontal bars. The notched portion represents a confidence interval around the medians. A discrepancy between the notched sections on the graphs indicates a significant difference in position between the distribution medians. The blue dot corresponds to the mean of the represented property.

An analysis of these paired graphs for each of the studied properties showed that the wood provenance had an impact on these properties, except for the radial shrinkage for which

the differences between the two provenances were not significant at the $5 \%$ threshold.

The density and infradensity were very significantly higher in wood from the Sahelian zone compared to the Sudanian zone, i.e. 508 and $409 \mathrm{~kg} \cdot \mathrm{m}^{-3}$ vs. 444 and $359 \mathrm{~kg} \cdot \mathrm{m}^{-3}$, respectively. This difference in density between the two zones could be explained by the difference in growing conditions related to rainfall levels.

Tangential shrinkage was significantly much lower in wood from the Sahelian zone. However, radial shrinkage was not significantly different between the two regions. The latter result was in line with that obtained by Traoré (2009) on vène wood from Mali (Pterocarpus erinaceus). The author had not observed a significant difference in linear 

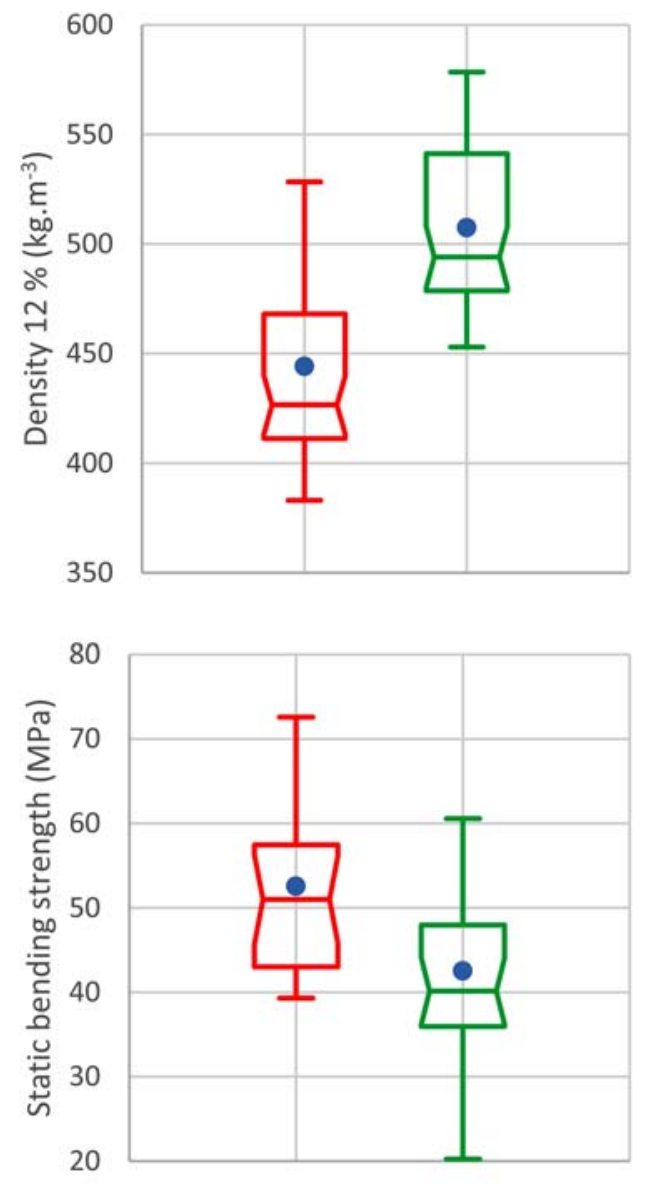

Sudanian zone
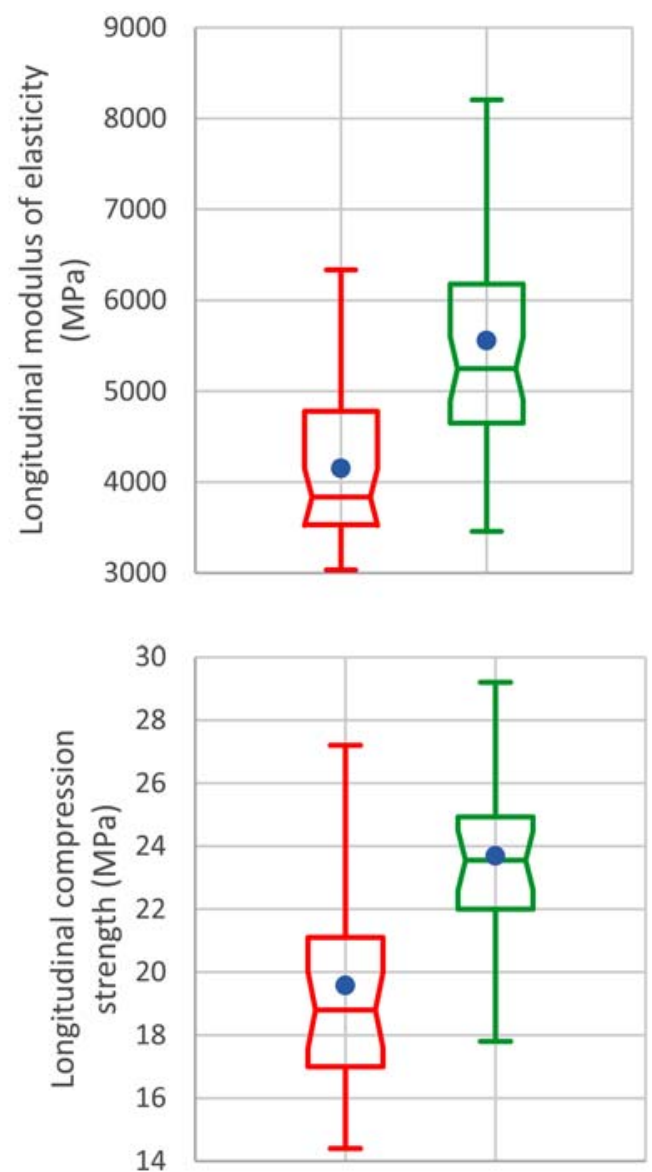

Sahelian zone

Figure 3 Continued

shrinkage between the two studied provenances, which were characterised by different growing conditions (Guinean zone and Sudanian zone).

This result had been attributed to the high extractive content in vène wood, which could limit the direct effect of anatomical changes related to growing conditions on drying shrinkage.

F. albida also had a very high extractive content, although it was lower than that of vène. The CIRAD wood database (Gérard et al. 2019) also gives a total extractive content of $8.6 \%$ for a Senegalese provenance, and $17.2 \%$ for vène from Senegal, while the results reported by Traoré (2009) indicated total extractive contents of between $15.5 \%$ and $19.5 \%$.

The volumetric shrinkage and fibre saturation point were significant between the two provenances $(9.5 \%$ and $28.9 \%$ in specimens from the Sudanian zone, and $7.7 \%$ and $23.7 \%$ in those from the Sahelian zone, respectively).

Similarly, the shrinkage anisotropy was significantly higher for the Sudanian zone Mazet and Nepveu (1991), Masseran and Mariaux (1985), and Charron et al. (2003) have shown that this anisotropy depends more on radial than tangential shrinkage. However, the tangential shrinkage in our case was significantly higher in the Sudanian zone, whereas the radial shrinkage values were identical for both zones, thereby explaining this difference in anisotropy.
The findings obtained for three mechanical characteristics studied were significantly different for the two provenances. The modulus of elasticity and the longitudinal compression strength were higher in wood from the Sahelian zone compared to the Sudanian zone (5555 vs. $4150 \mathrm{MPa}$ and 23.7 vs. 19.6 MPa, respectively). This difference should be considered relative to the higher density of wood ( $12 \%$ density and infradensity) from the Sahelian zone.

Contrary to the two previous properties, the modulus bending tensile strength was higher for the Sudanian zone (52.6 MPa) than for the Sahelian zone (42.5 MPa).

Similar studies carried out on different tropical species adapted to contrasting climatic conditions have highlighted the influence of the provenance on the main wood properties, but with varying trends.

Regarding P. erinaceus, Segla et al. (2015) and Traoré (2009) have documented a significant variation in density, infradensity and shrinkage anisotropy according to the provenance of woods from the Sudanian, Guinean, Malian and Togolese zones. These properties were found to increase with the extent of climatic dryness in the region of provenance, associated with harsher growing conditions. On the other hand, no significant difference between provenances was observed with regard to total radial shrinkage and total tangential shrinkage. On this same wood, Segla et al. (2020) showed that individual tree samples from the Sahelian zone 
were denser $\left(780 \pm 63 \mathrm{~kg} \cdot \mathrm{m}^{-3}\right)$, than those in the Guinean zone (basic density $=684 \pm 53 \mathrm{~kg} \cdot \mathrm{m}^{-3}$ ) and the Sudanian zone (basic density $=725 \pm 70 \mathrm{~kg} \cdot \mathrm{m}^{-3}$ ).

Out of four Pinus tecunumanii provenances from Guatemala sampled in four different departments, Eguiluz-Piedra and Zobel (2007) noted an increase in density over a westto-east gradient in relation to an increase in climatic dryness.

In a sample of Indian teak trees aged between 21 and 65 years, Bhat and Priya (2004) showed a significant influence of provenance on the physical and mechanical properties studied (density, modulus of elasticity, bending tensile strength and compressive strength). However, it is under an inverse trend compared to that of the previously mentioned results: wood from the Kanara provenance, a region where growing conditions are harsher (drier climate), had lower wood property results compared to wood from the Malabar provenance.

Depending on the species considered, the impact of growing conditions on the physical properties of tropical species adapted to different climatic conditions seem to vary markedly, sometimes with completely opposite trends.

\section{Conclusion}

This study was conducted on a limited sample size due to administrative, regulatory and logistical constraints at the sampling sites in Chad. However, it did reveal clear trends in the technological properties of $F$. albida wood and regarding the influence of the provenance on these properties.

Although F. albida is a phreatophytic species, the study revealed differences between its physical and mechanical wood properties according to the two study regions where the growing conditions differ, mainly due to differences in rainfall.

Wood sampled from the region with harsh growing conditions (Sahelian zone) had a higher density than that from the region with more favourable growing conditions (Sudanian zone). The same trend was noted for two of the three mechanical characteristics studied, i.e. longitudinal modulus of elasticity and compressive strength.

Woods from the Sahelian zone were also found to have better indicators of physical stability: total tangential shrinkage, total volume shrinkage, shrinkage anisotropy and fibre saturation point.

The better results obtained for the physical stability indicators and mechanical properties (except bending tensile strength) for wood from the Sahelian zone was in line with what was observed in local markets. Indeed, for products and objects made from F. albida wood, end users were found to prefer wooden items from the Sahelian zone, which were considered to be stronger and more stable than those from the Sudanian zone.

No significant differences between the two zones were noted for total radial shrinkage. This finding could be related to the high extractive content of $F$. albida wood.

This study of $F$. albida an emblematic multifunctional species throughout the Sudano-Sahelian zone should now be extended to encompass other provenances, particularly from Senegal, where it is also a major wood resource.
The study of the influence of climatic conditions on the F. albida wood characteristics could be extended to other major species growing in this area, particularly Balanites aegyptacia, another emblematic species of the region which has a similar distribution to that of F. albida in semiarid to arid zones.

\section{Disclosure statement}

No potential conflict of interest was reported by the author(s).

\section{References}

Bhat, K. M. and Priya, P. B. (2004) Influence of provenance variation on wood properties of teak from the Western Ghat Region in India. IAWA Journal, 25, 273-282. Available at: https://doi.org/10.1163/ 22941932-90000365

Charron, S., Jourez, B., Marchal, M. and Hébert, J. (2003) Étude comparative des caractéristiques physiques et mécaniques du bois des mélèzes d'Europe (Larix decidua Mill.), du Japon (Larix kaempferi (Lambert) Carr.) et de leur hybride (Larix $\mathrm{x}$ eurolepis Henry). Biotechnology, Agronomy, Society and Environment, 12. ISSN:17804507. Available at: https://popups.uliege.be/1780-4507/index.php/ base/issue/index.php?id=14436

Depommier, D. (1998) Etude phénologique de Faidherbia albida: effet de l'émondage, du site et de la dimension de l'arbre sur les phénophases de l'espèce au Burkina Faso. In C. Campa, C. Grignon, M. Gueye, and S. Hamon (eds.), L'acacia au Sénégal (Paris: ORSTOM), pp. 159-179. (Colloques et Séminaires). L'Acacia au Sénégal: Réunion Thématique, Dakar (SEN), 1996/12/03-05. ISBN: 2-7099-1423-9. Available at: https://www.documentation.ird.fr/hor/fdi:010016074

Dilla, A. M., Smethurst, P. J., Barry, K., Parsons, D. and Denboba, M. A. (2019) Tree pruning, zone and fertiliser interactions determine maize productivity in the Faidherbia albida (Delile) A. Chev Parkland agroforestry system of Ethiopia. Agroforestry Systems, 93(5), 1897-1907. Available at: https://doi.org/10.1007/s10457-018-0304-9

Eguiluz-Piedra, T. and Zobel, B. J. (2007) Geographic variation in wood properties of Pinus tecunumanii. Wood and Fiber Science, 18(1), 6875. Available at: https://wfs.swst.org/index.php/wfs/article/view/963

Gérard, J., Guibal, D., Cerre, J. C. and Paradis, S. (2016) Atlas des bois tropicaux - Caractéristiques technologiques et utilisations. Éditions Quae. RD 10, 78026 Versailles Cedex. 1002 p.

Gérard, J., Paradis, S. and Thibaut, B. (2019) Survey on the chemical composition of several tropical wood species. Bois et Forêts des Tropiques, 342, 79-91.

Kini, L. (2018) Utilisation des gousses de Faidherbia albida (Del.) A. Chev dans I'alimentation des bovins en zones urbaine et péri-urbaine de la ville de Banfora (Burkina Faso). Burkina Faso. Mémoire du fin de cycle d'ingénieur du développement rural: option élevage, Institut du développement rural de Burkina Faso, 61p.

Koech, G., Ofori, D., Muigai, A. W., Muriuki, J., Anjarwalla, P. and Mowo, J. G. (2016) Variation in the response of eastern and southern Africa provenances of Faidherbia albida (Delile A. Chev) seedlings to water supply: A greenhouse experiment. Global Ecology and Conservation, 8, 31-40. Available at: https://doi.org/10.1016/j.gecco. 2016.08.005

Kokutse, A. D., Brancheriau, L. and Chaix, G. (2010) Rapid prediction of shrinkage and fibre saturation point on teak (Tectona grandis) wood based on near-infrared spectroscopy. Annals of Forest Science, 67(4), 403. Available at: https://doi.org/10.1051/forest/2009123

Kržišnik, D., Brischke, C., Lesar, B., Thaler, N. and Humar, M. (2019) Performance of wood in the Franja partisan hospital. Wood Material Science \& Engineering, 14(1), 24-32. https://doi.org/10.1080/ 17480272.2018 .1438512

Masseran, C. and Mariaux, A. (1985) Anisotropie de retrait et structure du bois: recherche de l'influence des caractères morphologiques transverses des fibres. Bois et forêts des tropiques, 209, 35-47. Available at: https://doi.org/10.19182/bft1985.209.a19537 
Mazet, J. and Nepveu, G. (1991) Relations entre caractéristiques de retrait et densité du bois chez le pin sylvestre, le sapin pectiné et l'épicéa commun. Annals of Forest Science, 48, 87-100. Available at: https:// doi.org/10.1051/forest:19910107

Mignon, A. and Do, F. (1999) ACFLOW - Un modèle d'analyse des transferts hydriques chez un acacia phréatophyte (Dakar: IRD). 25 p. Available at: http://www.documentation.ird.fr/hor/fdi:010020525

Roupsard, O., Ferhi, A., Granier, A., Pallo, F., Depommier, D., Mallet, B., Joly, H. I. and Dreyer, E. (1999) Reverse phenology and dry-season water uptake by Faidherbia albida (Del.) A. Chev. in an agroforestry parkland of Sudanese West Africa. Functional Ecology, 13, 460-472. Available at: https://doi.org/10.1046/j.1365-2435.1999.00345

Segla, K. N., Adjonou, K., Rabiou, H., André Bationo, B., Mahamane, A., Guibal, D., Kokou, K., Chaix, G., Kokutse, A. D. and Langbour, P. (2020) Relations between the ecological conditions and the properties of Pterocarpus erinaceus Poir. wood from the Guinean-Sudanian and Sahelian zones of West Africa. Holzforschung, 74(11), 999-1009. Available at: https://doi.org/10.1515/hf-2019-0250
Segla, K. N., Kokutse, A. D., Adjonou, K., Langbour, P., Chaix, G., Guibal, D. and Kokou, K. (2015) Caractéristiques biophysiques du bois de Pterocarpus erinaceus (Poir.) en zones guinéenne et soudanienne au Togo. Bois et Forêts des Tropiques, 324, 51-64. Available at: https:// doi.org/10.19182/bft2015.324.a31266

Sileshi, G. W. (2016) The magnitude and spatial extent of influence of Faidherbia albida trees on soil properties and primary productivity in drylands. Journal of Arid Environments, 132, 1-14. Available at: https://doi.org/10.1016/j.jaridenv.2016.03.002

Traoré, B. (2009) Influence de la structure anatomique et des métabolites secondaires sur les propriétés physiques et la qualité acoustique du bois de vène (Pterocarpus erinaceus - Poir.) provenant du Mali. Thèse de Doctorat, Département des Sciences du Bois et de la Forêt, Université Laval, Québec, Canada, 206 p. Available at: http://hdl. handle.net/20.500.11794/21319

Wood, P. J. (1989) Faidherbia albida (Del.) A. Chev. (Synonyme: Acacia albida Del.): A Monograph (Nogent-sur-Marne: CTFT). 66 p., ISBN: 285411-004-8. Available at: https://agritrop.cirad.fr/547995/ 